\title{
OPEN
}

Published online: 13 November 2019

\section{Author Correction: Ursodeoxycholic acid improves liver function via phenylalanine/tyrosine pathway and microbiome remodelling in patients with liver dysfunction}

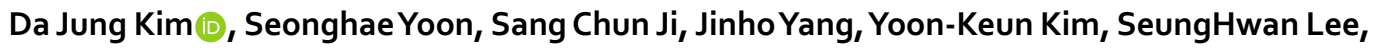
Kyung-Sang Yu, In-Jin Jang, Jae-Yong Chung \& Joo-Youn Cho iD

Correction to: Scientific Reports https://doi.org/10.1038/s41598-018-30349-1, published online 08 August 2018

The Article contains an error in the legend of Table 1.

"Data are the mean \pm standard deviation. ${ }^{\dagger} \mathrm{P}<0.05$ (Friedman test) between pre-dose and week 4 ; ${ }^{\ddagger} \mathrm{P}<0.05$ between pre-dose and week 8 . ns, not significant."

should read:

"Data are the mean \pm standard error of mean. ${ }^{\dagger} \mathrm{P}<0.05$ (Wilcoxon signed-rank test) between pre-dose and week 4 ; ${ }^{\ddagger} \mathrm{P}<0.05$ between pre-dose and week 8 . ns, not significant."

(c) (i) Open Access This article is licensed under a Creative Commons Attribution 4.0 International cc. License, which permits use, sharing, adaptation, distribution and reproduction in any medium or format, as long as you give appropriate credit to the original author(s) and the source, provide a link to the Creative Commons license, and indicate if changes were made. The images or other third party material in this article are included in the article's Creative Commons license, unless indicated otherwise in a credit line to the material. If material is not included in the article's Creative Commons license and your intended use is not permitted by statutory regulation or exceeds the permitted use, you will need to obtain permission directly from the copyright holder. To view a copy of this license, visit http://creativecommons.org/licenses/by/4.0/.

(C) The Author(s) 2019 